\title{
SIMULATION OF FUZZY LOGIC CONTROLLER FOR PEM FUEL CELL BASED HYBRID CASCADED MULTILEVEL INVERTER
}

\author{
Dr.R.SEYEZHAI \\ Associate Professor, Renewable Energy Conversion Laboratory, Department of EEE, \\ SSN College of Engineering, Chennai
}

\begin{abstract}
:
The power generated in a proton exchange membrane fuel cell based system depends on the hydrogen and oxygen flows, the regulation of pressure and management of water and heat .One of the important operating variable is the reactant utilization which is directly proportional to fuel cell stack current. When a load is connected to the fuel cell system, the control system must control the flow rate of hydrogen in order to avoid degradation of fuel cell (FC) voltage. Therefore, the objective of the paper is to regulate the input fuel flow to achieve the desired output power. Various control strategies proposed in the literature do not consider the dynamic model of fuel cell system and fuel flow controller. This paper presents the development of fuzzy logic controller for fuel cell based Hybrid Cascaded MultiLevel Inverter(MLI). A MATLAB/SIMULINK control structure for the overall FC based system has been presented which includes the local fuzzy controllers for Interleaved Boost Converter (IBC), HCMLI and the fuel cell. The performance has been compared with PI controller.
\end{abstract}

\section{INTRODUCTION}

The mathematical model of the Proton Exchange Membrane (PEM)FC has been used to design the fuzzy logic controller (FLC) for fuel cell. The fuel cell control problem is translated into an output current control requirement to be realized by the power conditioning unit in order to ensure optimal operation for a given fuel flow rate.. FLC for IBC has been designed to regulate the output voltage by adjusting the duty ratio to the required value. Fuzzy Logic Controller (FLC) for HCMLI regulates the output voltage for all types of loads (linear and non-linear load) with minimum THD upto the rated conditions. The system is tested under a voltage disturbance and this effect is observed in all parameters like fuel cell voltage, PEMFC power, hydrogen flow rate, IBC output voltage and load power. The slow response of the fuel cell is compensated by HCMLI.

\section{CONTROL STRATEGY FOR FC BASED HCMLI}

Fuzzy logic control is a practical alternative for constructing non-linear controllers via the use of heuristic information. FLC consists of the rule base, fuzzification, inference engine and defuzzification[1]. The rule base collects the control rules which describe expert's knowledge and experience in the fuzzy set. In the fuzzification process, the numerical inputs are converted into linguistic fuzzy values. Then, from the fuzzy values and the already established rule base,

DOI : 10.14810/elelij.2015.4106 
linguistic control values are generated in the inference engine. The linguistic inference results are converted into numerical output again in the defuzzification process. The centre of gravity method is used for defuzzification. The block diagram of fuzzy logic controller for FC based HCMLI is shown in Fig.1. Fuel cell is connected to the load via interleaved boost converter and single-phase HCMLI. The overall control structure includes controller design methodologies for fuel cell and power conditioning units. Each component will be controlled by its own local controller so that the subsystem is stable and the power demand is satisfied as much as possible. Fuel cell controller regulates the flow rate of hydrogen in PEMFC and the controller for IBC regulates its output voltage and the controller for HCMLI controls the load voltage. Power flow from PEMFC to the load is controlled by controlling the flow rate of hydrogen $[2,3]$. The details of the controller based on fuzzy logic are presented in this chapter and its performance is compared with PI controller.

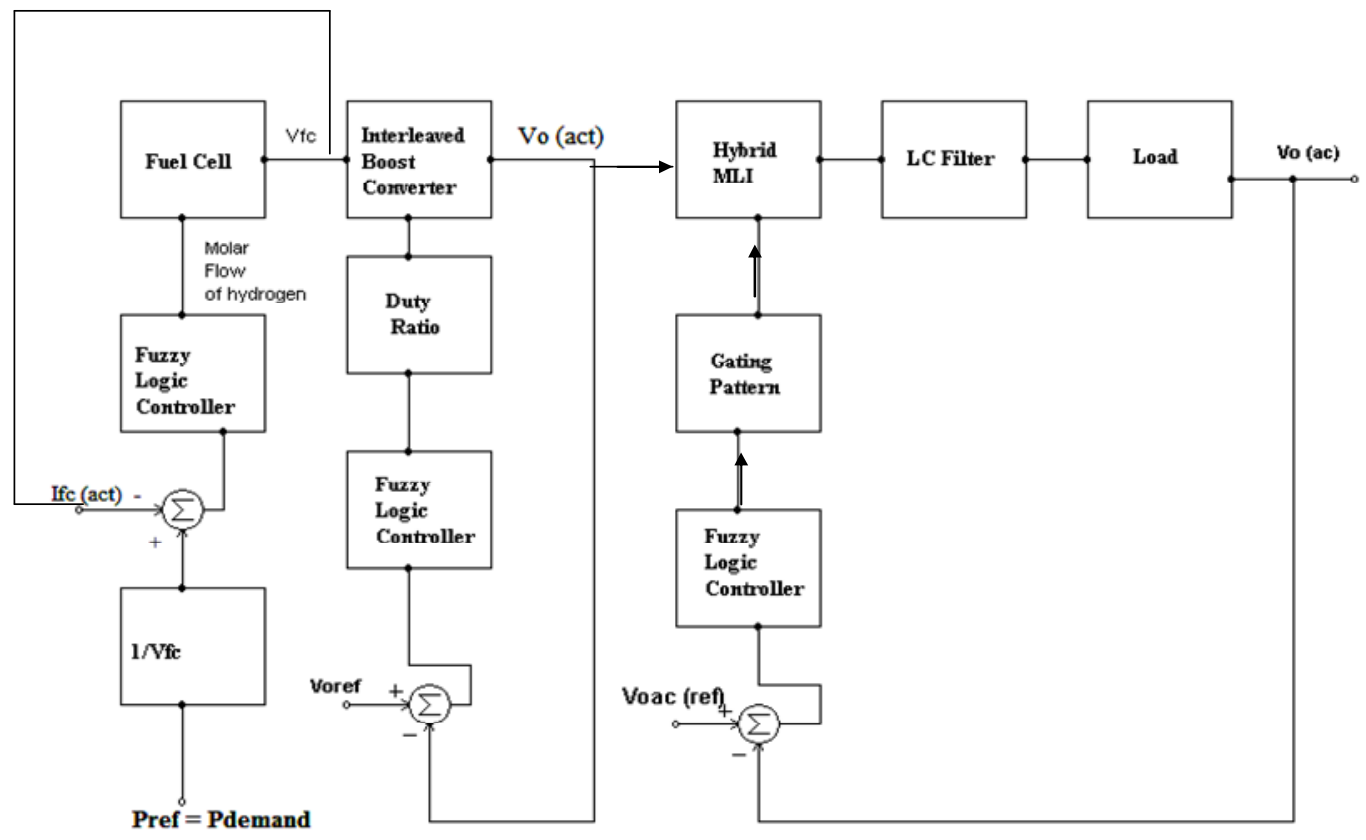

Figure 1. Block diagram of control structure for FC based HCMLI

\section{(1) FUEL CELL CONTROLLER}

The active power flow from the PEMFC to the load can be controlled by using the following methods:

1. The fuel cell can be operated at the maximum power point for a given fuel flow. This method results in lower output voltage, lower thermodynamic efficiency and hence increases the operational cost of the fuel cell stack.

2. The fuel cell can be operated at maximum efficiency for a given fuel flow. Maximum thermodynamic efficiency is achieved at a high output voltage and therefore low power density. Hence, this mode of operation results at a lower operational cost but a higher capital cost to achieve a certain power output. 
3. Operation of the fuel cell at an optimal fuel utilization point (by controlling the flow rate of hydrogen) which is employed in this research work $[4,5]$.

While designing the controller the following constraints should be observed:

- Underused fuel: If the fuel utilization drops below a certain limit, the cell voltage will rise rapidly.

- Overused fuel: If the fuel utilization increases beyond a certain value, the cells may suffer from fuel starvation and can be permanently damaged.

- Under voltage: The fuel cell characteristic poses a lower cell voltage limit of approximately $0.5 \mathrm{~V}$ beyond which the cell voltage decreases very steeply with increasing current.

For satisfying the above mentioned constraints, the aim of the controller is to maintain optimal hydrogen utilization $\left(\mathrm{U}_{\mathrm{opt}}\right)$ around $85 \%$. High utilizations are considered desirable because they minimize the required fuel and oxidant flow for a minimum fuel cost and compressor load and size[4] .

The reacting fuel quantity $\left(q_{H 2}^{r}\right)$ is directly proportional to the output current and hence the desired utilization is converted to a corresponding output current demand given by

$$
I_{\text {demand }}=\frac{U_{o p t}}{2 K_{r}} \cdot q_{H 2}^{r}
$$

The range of $U_{\text {opt }}$ is $80-90 \%$ and the limitation for the demand current is given by

$$
\frac{0.8 q_{H 2}^{i n}}{2 K_{r}}=I_{f_{c \min }}=\leq I_{f_{c r e f}} \leq I_{f_{c \max }}=\frac{0.9 q_{H 2}^{i n}}{2 k_{r}}
$$

Therefore the fuel cell control problem is translated into an output current control requirement to be realized by the power conditioning unit in order to ensure optimal operation for a given fuel flow rate. Hence, the power delivered by the fuel cell is directly related to its fuel consumption at the selected optimum operating point. In other words, the power demand is converted into a current demand input by dividing with the stack output voltage as [6].

$$
I_{f c(r e f)}=\frac{P_{r e f}}{V_{f c}}
$$

A fuzzy logic controller has been designed to overcome the transient conditions in fuel cell and the control structure is shown in Fig.2.

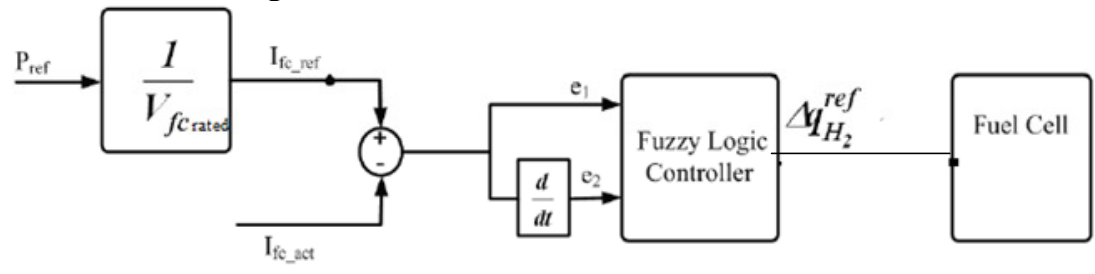

Figure 2. Control structure for fuel cell 
The inputs to the fuzzy logic controller are scaled versions of both the fuel cell current error and its derivative and hydrogen molar flow is assigned to the output of the controller. Triangle membership functions are used for fuzzification of inputs. Each of the FLC input signals and output signals are assigned three linguistic variables namely, Small (S), Medium (M), Large (L), Negative $(\mathrm{N})$, Zero $(\mathrm{Z})$ and Positive $(\mathrm{P})$ respectively. The rules are framed as shown in Table 1.

Table 1 Fuzzy rule for the flow rate of hydrogen

\begin{tabular}{|c|c|c|c|c|}
\hline \multirow{2}{*}{\multicolumn{2}{|c|}{$\Delta q_{H_{2}} r e f$}} & \multicolumn{3}{|c|}{$\mathbf{e}_{2}$} \\
\hline & & $\mathbf{N}$ & $\mathbf{Z}$ & $\mathbf{P}$ \\
\hline & $\mathrm{S}$ & $\mathrm{NL}$ & $\mathrm{Z}$ & PS \\
\hline & $\mathrm{M}$ & $\mathrm{NL}$ & $\mathrm{Z}$ & PS \\
\hline $\mathrm{e}_{1}$ & $\mathrm{~L}$ & NS & PS & $\overline{\mathrm{PL}}$ \\
\hline
\end{tabular}

\section{(2) CONTROLLER FOR INTERLEAVED BOOST CONVERTER}

The output power of fuel cell is controlled and conditioned by a high power interleaved boost converter so that the electric characteristic of the converter should match that of the fuel cell. Fuzzy controller is designed to adapt to the nonlinear property of IBC under varying operating points. Figure. 3 shows the control structure of IBC. The unregulated output voltage of fuel cell is fed to IBC. The duty ratio of the converter is adjusted using FLC in order to provide the desired output voltage against variations in flow rate of hydrogen, load or in the operating parameters of fuel cell. The duty ratio is changed by changing the pulses fed to the switches in IBC $[7,8]$. The response time of IBC is faster compared to fuel cell which alters the fuel flow. The error and change in error are the inputs to FLC. The FLC generates control signal based upon the inputs and rule base. The control signal alters the duty ratio to generate the desired output voltage. The membership functions of the controller for IBC is shown in Figure 4.

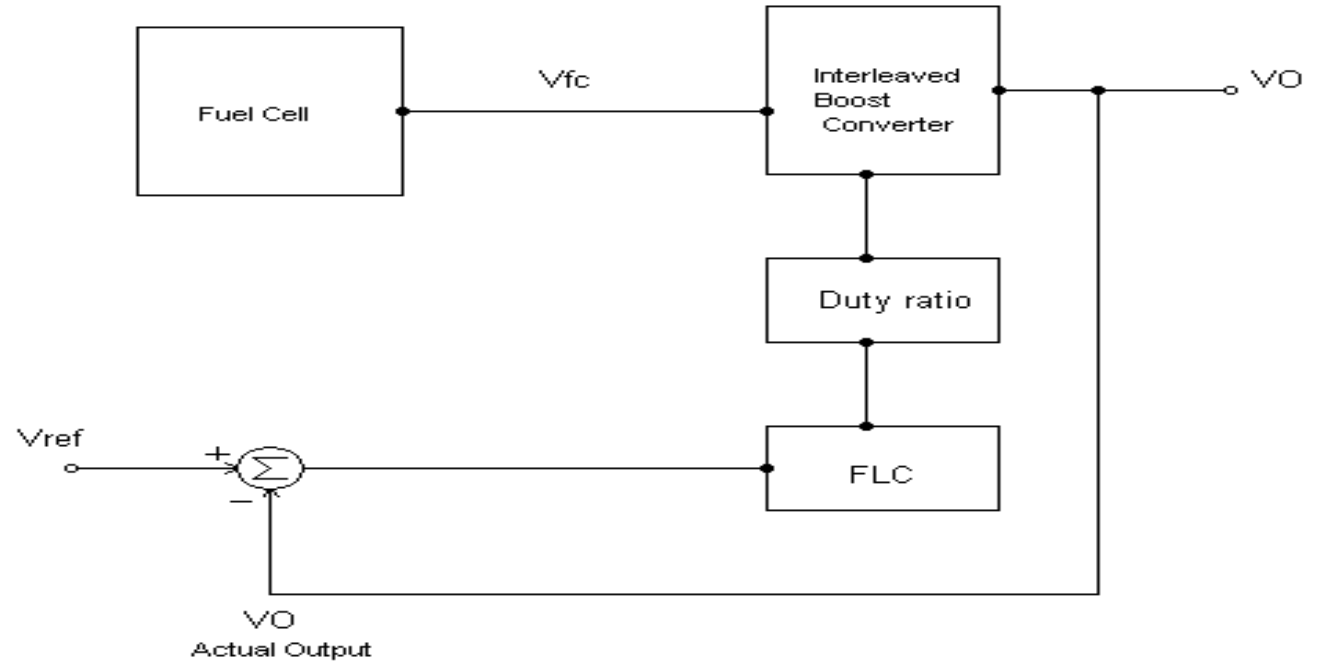

Figure 3. Control structure for IBC 
Electrical and Electronics Engineering: An International Journal (ELELIJ) Vol 4, No 1, February 2015

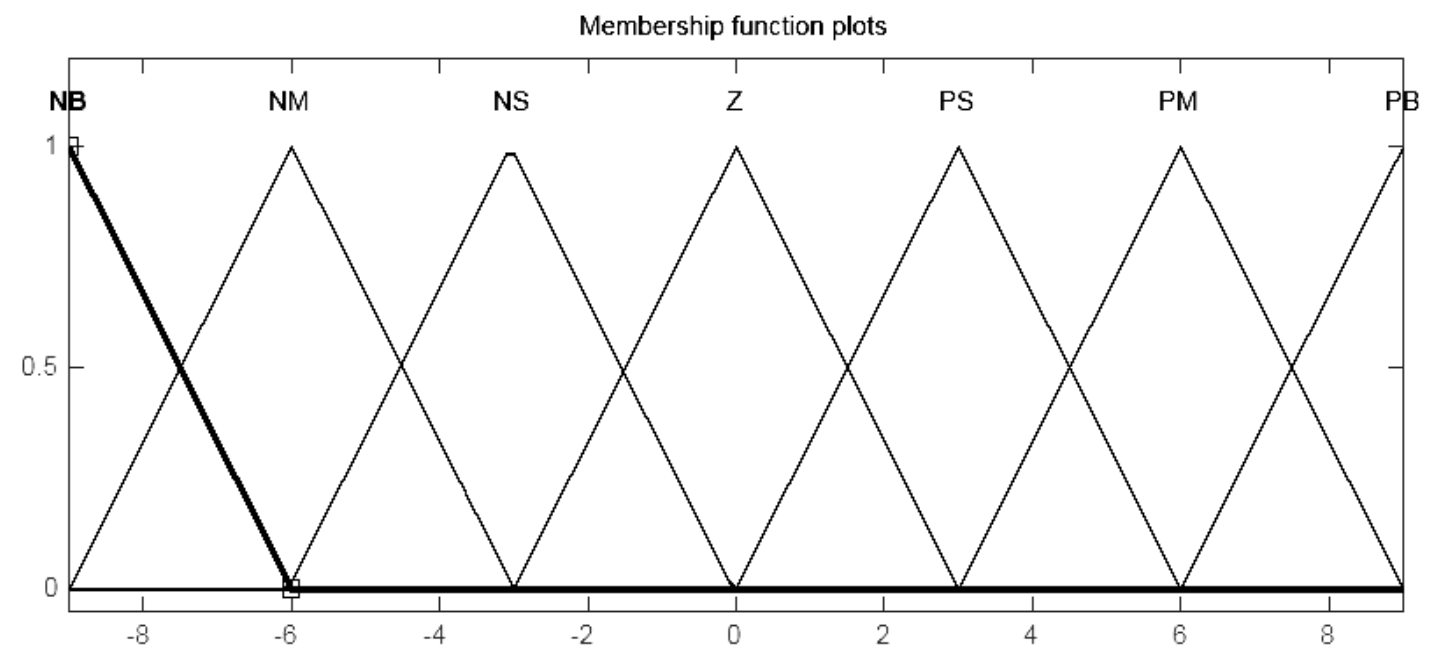

Figure .4 Membership Functions for the inputs $\left(\mathrm{e}_{1}\right.$ and $\left.\mathrm{e}_{2}\right)$

The input is divided into seven sets of triangular shapes which are NB (negative big), NM (negative medium), NS (negative small), Z (zero), PS (positive small), PM (positive medium) and $\mathrm{PB}$ (positive big). The membership function for the the change in duty ratio $(\Delta d)$ is shown in Figure 5.

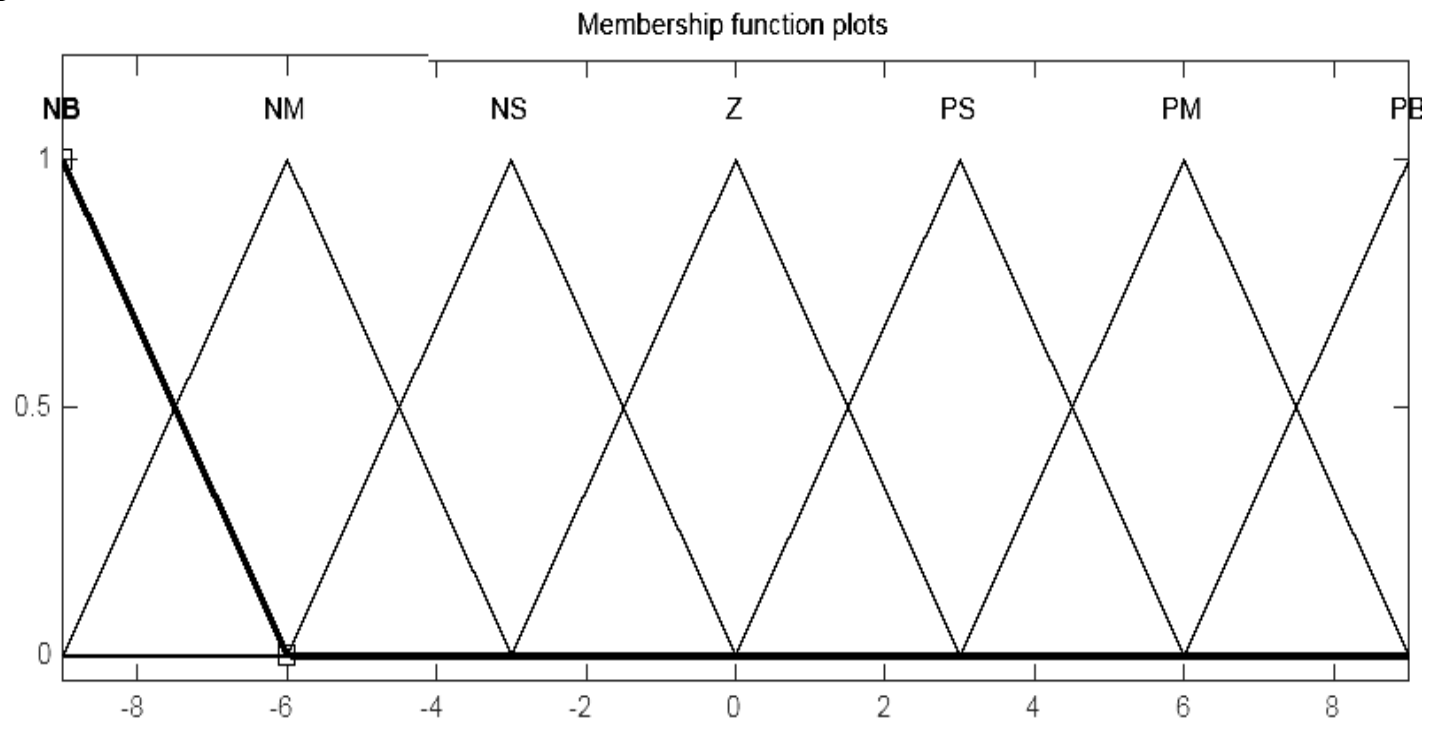

Figure .5 Membership Functions for the output $(\Delta d)$

The rules for fuzzy controller for IBC is shown in Table .2 
Table .2 Fuzzy rule base for duty ratio control of IBC

\begin{tabular}{|c|c|c|c|c|c|c|c|c|}
\hline \multicolumn{2}{|c}{$(\Delta \boldsymbol{d})$} & \multicolumn{7}{|c|}{$\mathbf{e}_{2}$} \\
\cline { 2 - 10 } & NB & NM & NS & Z & PS & PM & PB \\
\hline \multirow{4}{*}{$\mathrm{e}_{1}$} & NB & NB & NB & NB & NB & NM & NS & Z \\
\cline { 2 - 10 } & NM & NB & NB & NB & NM & NS & Z & PS \\
\cline { 2 - 10 } & NS & NB & NM & NS & NS & Z & PS & PM \\
\cline { 2 - 10 } & Z & NB & NM & NS & Z & PS & PM & PB \\
\cline { 2 - 10 } & PS & NM & NS & Z & PS & PM & PM & PB \\
\cline { 2 - 9 } & PM & NS & Z & PS & PM & PB & PB & PB \\
\cline { 2 - 10 } & PB & Z & PS & PM & PB & PB & PB & PB \\
\hline
\end{tabular}

The three-dimensional control surface for the rule base is shown in Figure .6.

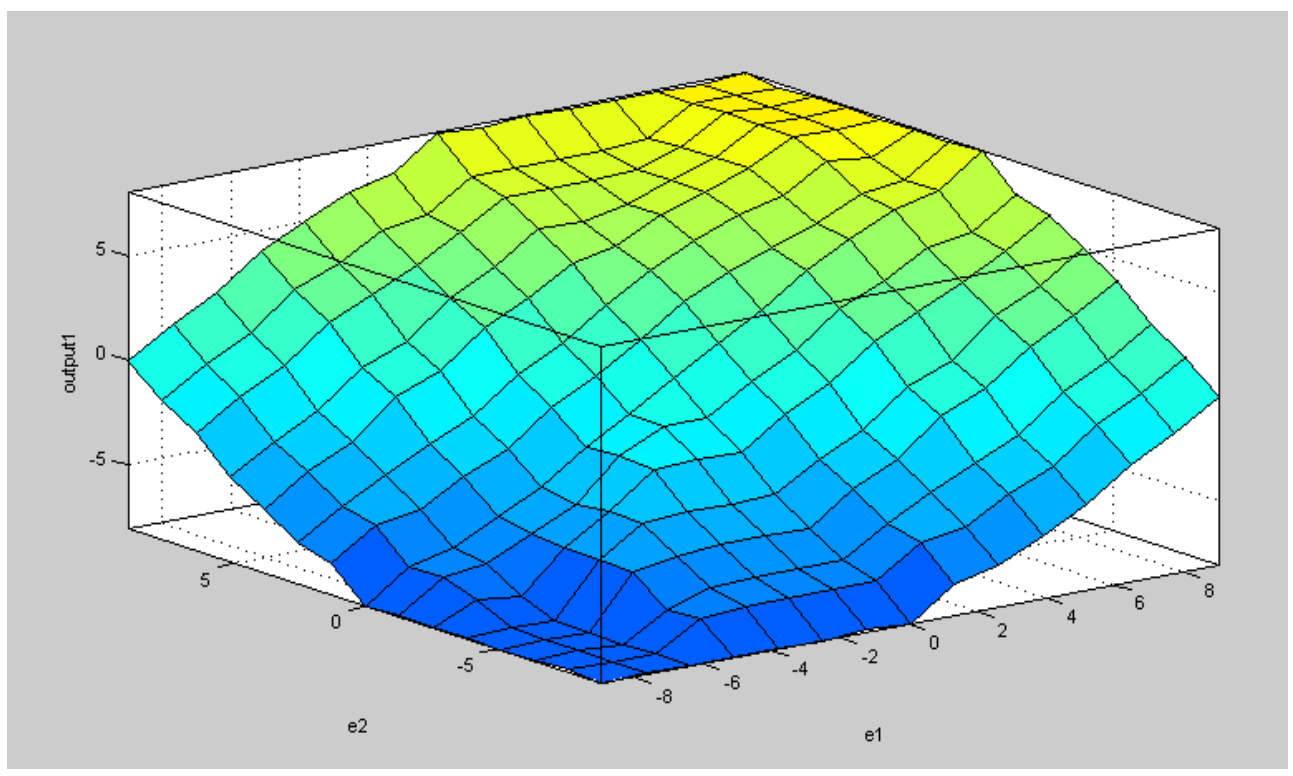

Figure .6 Control surface of FLC for the IBC

\section{CONTROLLER FOR HCMLI}

The output of IBC is the boosted voltage that is fed to the hybrid cascaded MLI. The function of the controller is to provide a regulated load voltage under rated conditions with minimum THD 9,10$]$. The controller structure for HCMLI is shown in Figure 7. The inputs to the FLC are scaled versions of both the rms voltage error and its derivative and the output is the change in the modulation index. Seven uniformly distributed triangle membership functions are used for the fuzzification of inputs. The rule base is designed so that the actual rms voltage can reach its command value as quick as possible without overshoot. Membership functions for the inputs and output is shown in Figs .8 \& 9. 
Electrical and Electronics Engineering: An International Journal (ELELIJ) Vol 4, No 1, February 2015

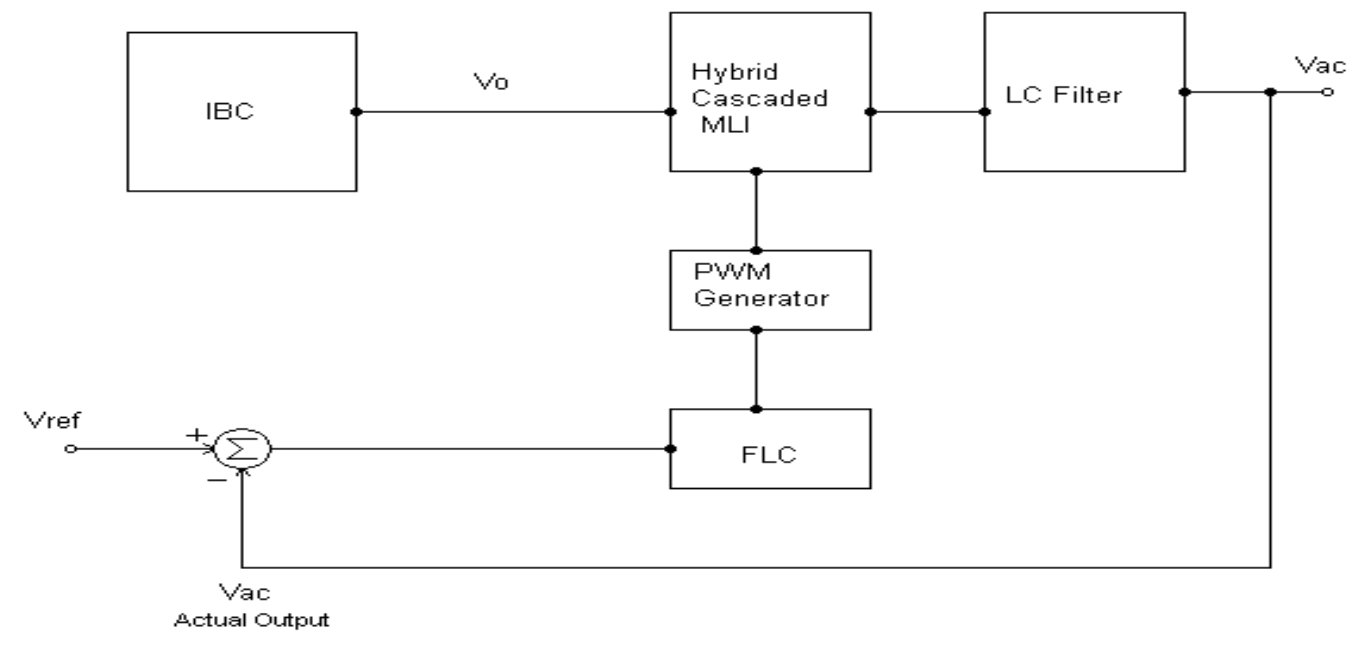

Figure 7 Controller structure for HCMLI

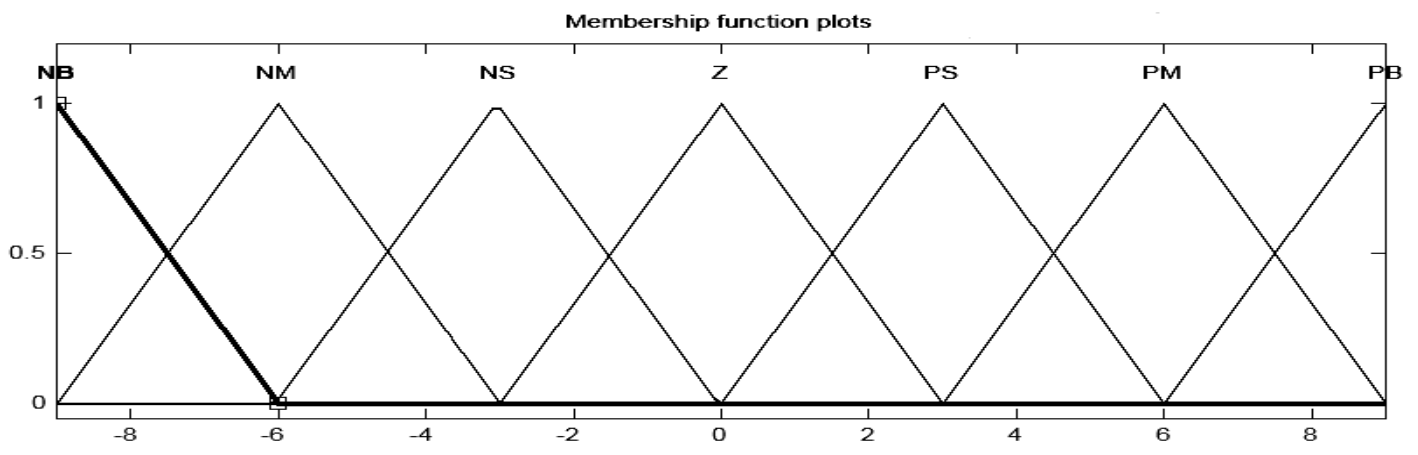

Figure .8 Membership functions for the HCMLI inputs $\left(\mathrm{e}_{1}\right.$ and $\left.\mathrm{e}_{2}\right)$

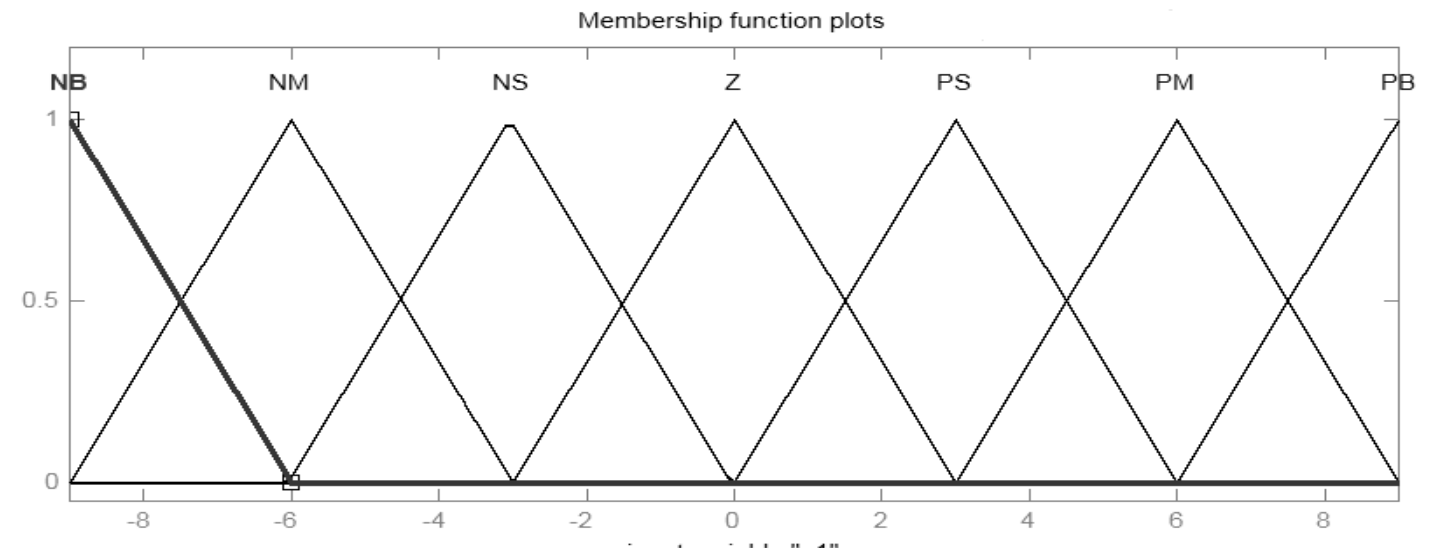

Figure .9 Membership functions for the HCMLI output $\left(\Delta m_{a}\right)$

The rule base of controller HCMLI is shown in Table .3. 
Electrical and Electronics Engineering: An International Journal (ELELIJ) Vol 4, No 1, February 2015

Table .3 Fuzzy rule base for HCMLI

\begin{tabular}{|c|c|c|c|c|c|c|c|c|}
\hline \multirow{2}{*}{\multicolumn{2}{|c|}{$\Delta m_{a}$}} & \multicolumn{7}{|c|}{$\mathbf{e}_{2}$} \\
\hline & & NB & $\mathbf{N M}$ & NS & $\mathbf{Z}$ & PS & $\mathbf{P M}$ & $\mathbf{P B}$ \\
\hline \multirow{7}{*}{$\mathrm{e}_{1}$} & NB & $\mathrm{PB}$ & PB & PB & $\mathrm{PM}$ & $\mathrm{PM}$ & PM & PS \\
\hline & $\mathrm{NM}$ & $\mathrm{PB}$ & PB & PM & PM & PM & $\mathrm{Z}$ & NB \\
\hline & $\mathrm{NS}$ & PB & PM & PM & PM & PS & NS & NB \\
\hline & $\mathrm{Z}$ & PB & PM & PS & $\mathrm{Z}$ & NS & NM & NB \\
\hline & PS & $\mathrm{PB}$ & PS & $\mathrm{S}$ & $\mathrm{NM}$ & $\mathrm{NM}$ & $\mathrm{NM}$ & $\mathrm{NB}$ \\
\hline & PM & PB & $\mathrm{Z}$ & $\mathrm{NM}$ & $\mathrm{NM}$ & $\mathrm{NM}$ & NB & $\mathrm{NB}$ \\
\hline & PB & $\mathrm{NS}$ & NM & $\mathrm{NM}$ & $\mathrm{NM}$ & NB & NB & NB \\
\hline
\end{tabular}

\section{SIMULATION RESULTS}

In order to show the effectiveness of proposed fuzzy logic control strategy, the simulation model of the proposed FC based HCMLI has been built in MATLAB /SIMULINK environment. In order to test the dynamics of the proposed controller, a voltage disturbance is introduced at $0.25 \mathrm{~s}$ and $0.5 \mathrm{~s}$. Fuzzy logic controller regulates the voltage against the disturbance as shown in Figure .10. The output quickly settles at the set point.

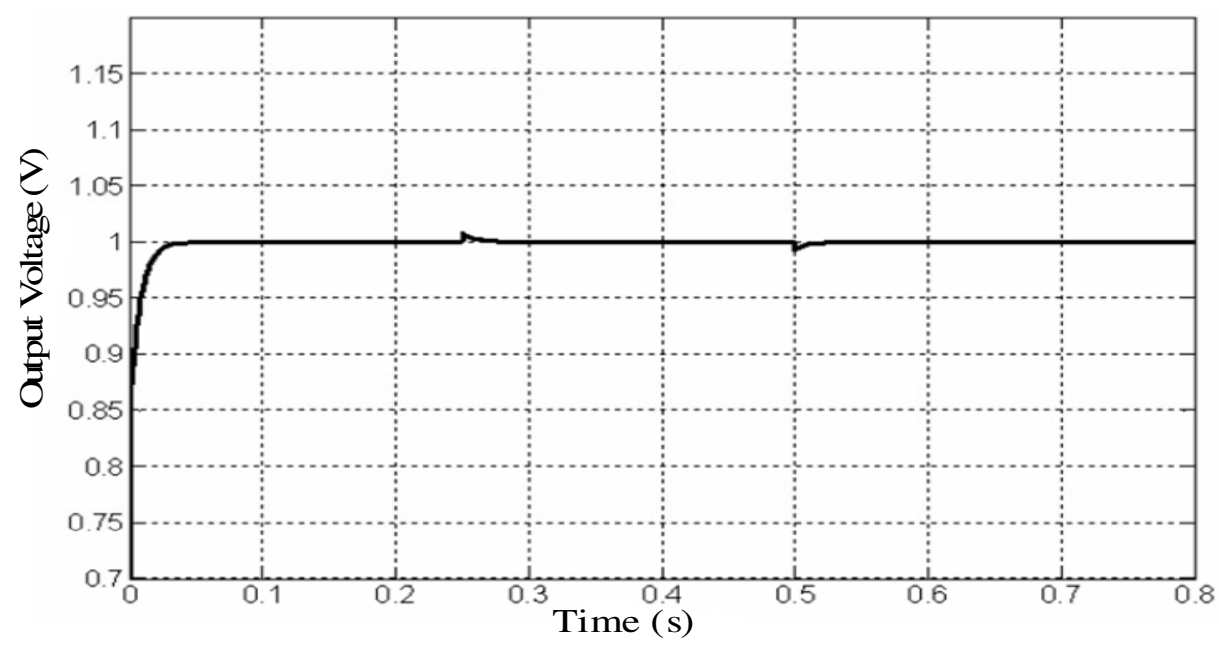

Figure .10 Regulated output voltage (pu) of HCMLI

The response of hydrogen flow rate, IBC output voltage and fuel cell voltage is shown in Figures 11, 12 and 13. 
Electrical and Electronics Engineering: An International Journal (ELELIJ) Vol 4, No 1, February 2015

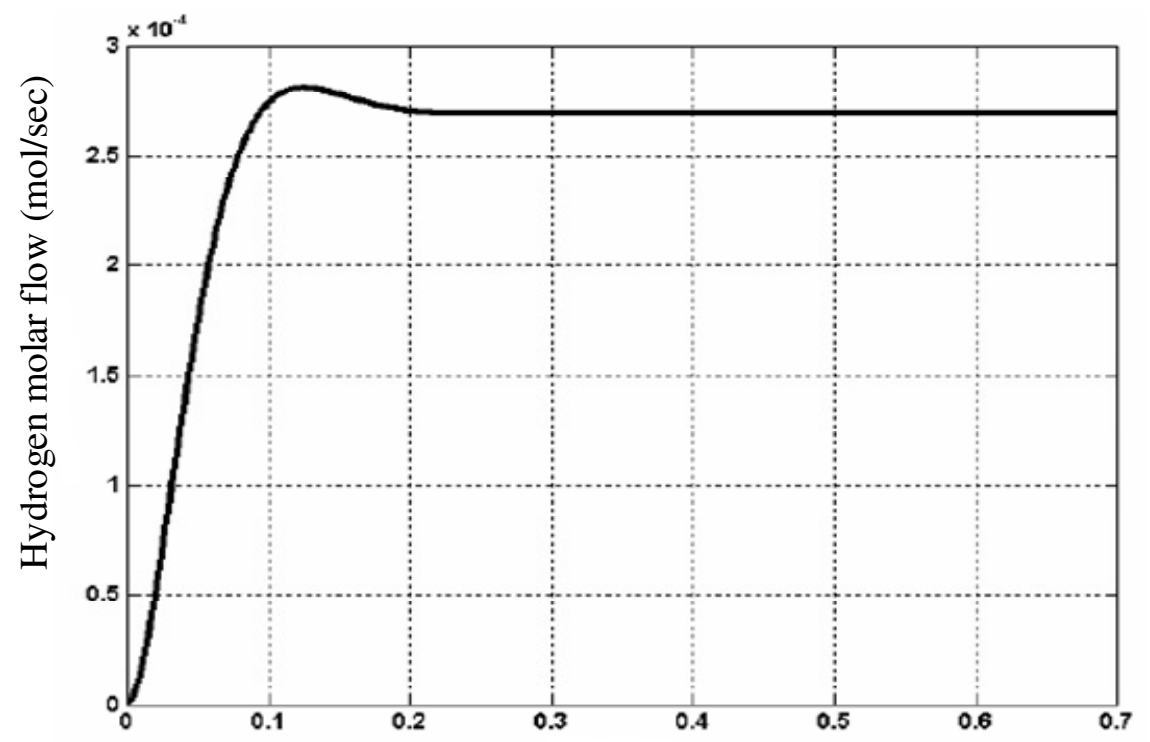

Time (s)

Figure 11 Variation in hydrogen molar flow of PEMFC

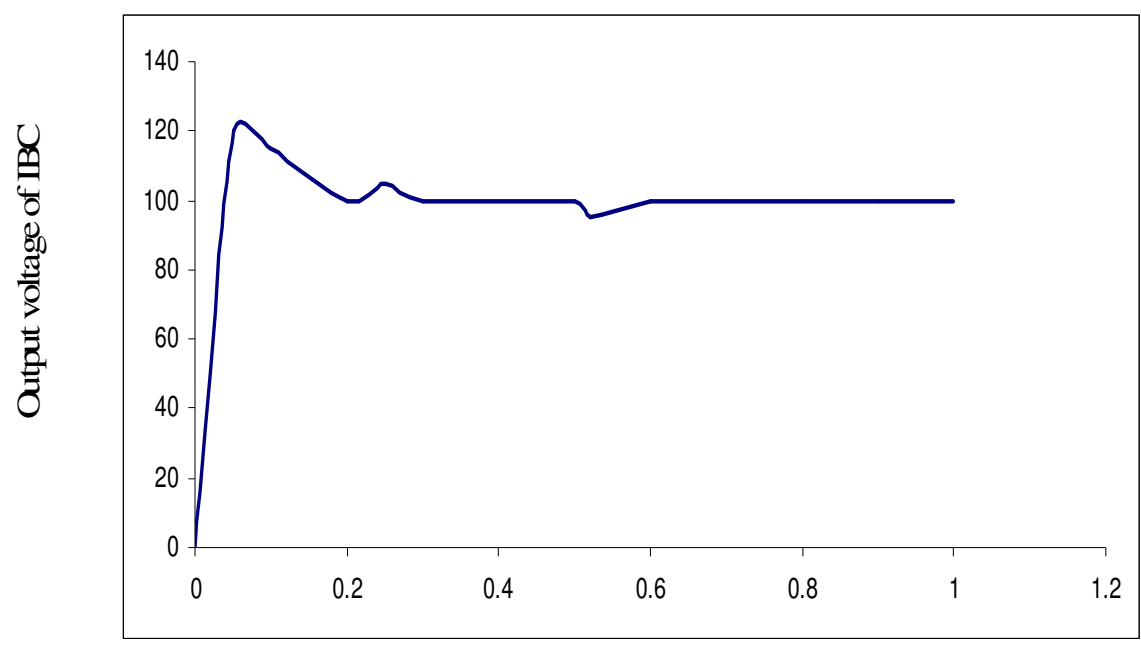

Time (s)

Figure 12 Response of IBC output voltage during disturbance 
Electrical and Electronics Engineering: An International Journal (ELELIJ) Vol 4, No 1, February 2015

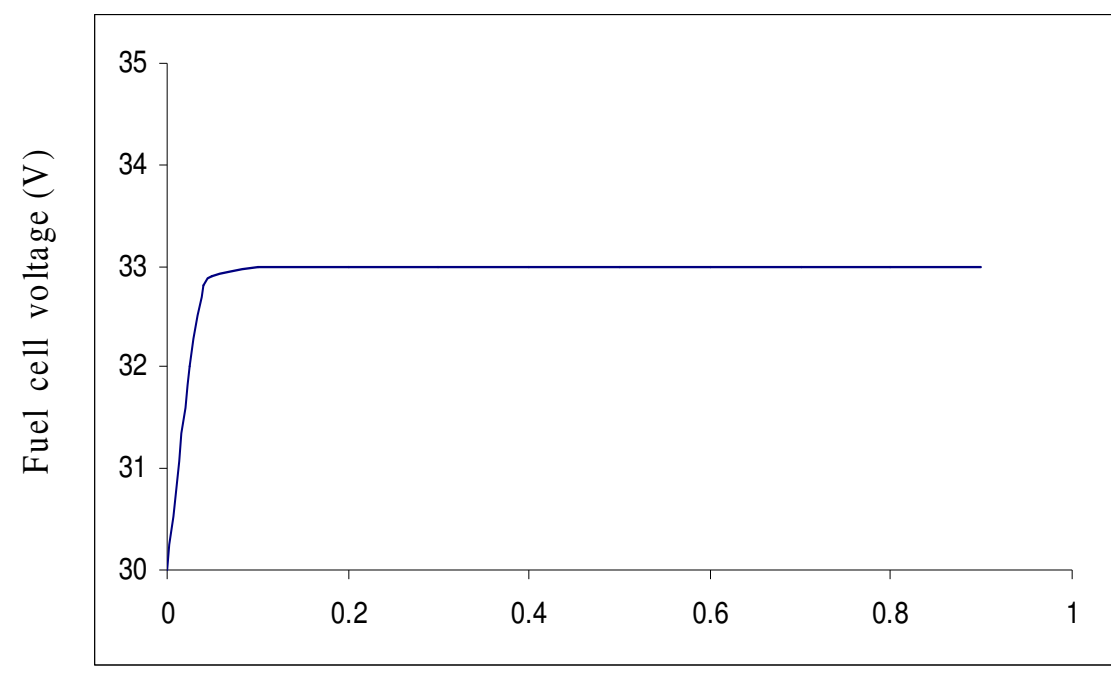

Time (s)

Figure 13 Response of fuel cell voltage during disturbance

The output voltage of IBC in Figure 12 shows a variation during the transients. However, the magnitude of ripple is less and it is quickly damped out. The simulation results clearly show that the fuel cell based HCMLI system has not been affected due to the disturbance.

\subsection{Simulation Results for HCMLI}

Figure .14 shows the steady-state response of HCMLI (output voltage and current waveforms) with fuzzy control. Table .4 shows the simulation parameters for HCMLI.

Table 4 Simulation parameters for HCMLI

\begin{tabular}{|l|l|}
\hline \multicolumn{1}{|c|}{ Parameters } & \multicolumn{1}{c|}{ Value } \\
\hline Reference voltage & $100 \mathrm{~V}$ \\
\hline Modulation index & 0.90 \\
\hline Filter (L \& C) & $\mathrm{L}=2.2 \mathrm{mH}$ and C $=220 \mathrm{uF}$ \\
\hline Rated output frequency & $50 \mathrm{~Hz}$ \\
\hline Load (RL ) & $\mathrm{R}=30 \mathrm{ohms}$ and $\mathrm{L}=0.024 \mathrm{H}$ \\
\hline
\end{tabular}


Electrical and Electronics Engineering: An International Journal (ELELIJ) Vol 4, No 1, February 2015

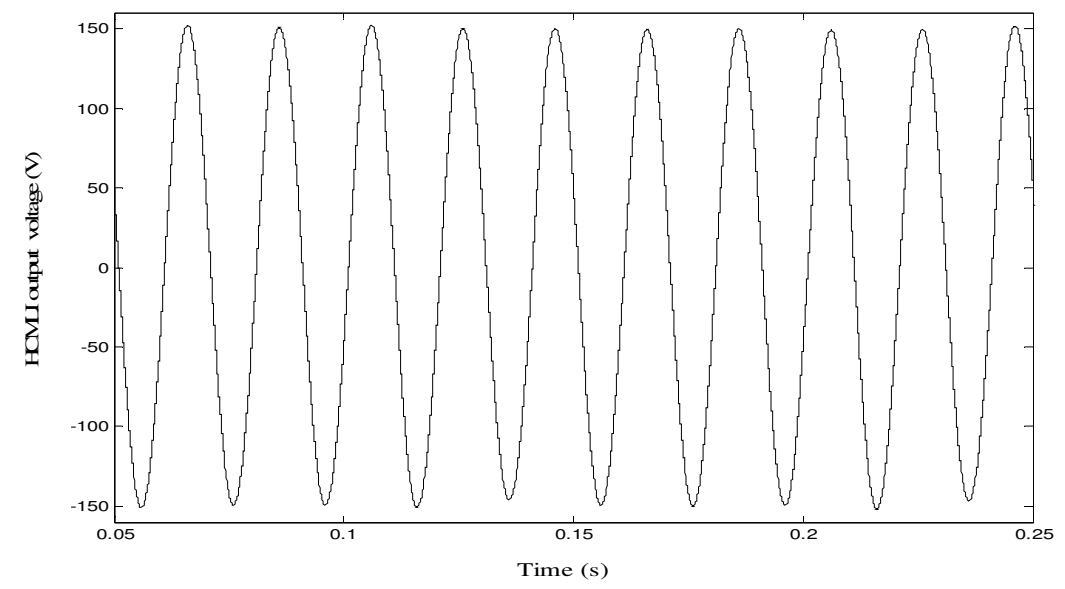

(a) Load Voltage of HCMLI

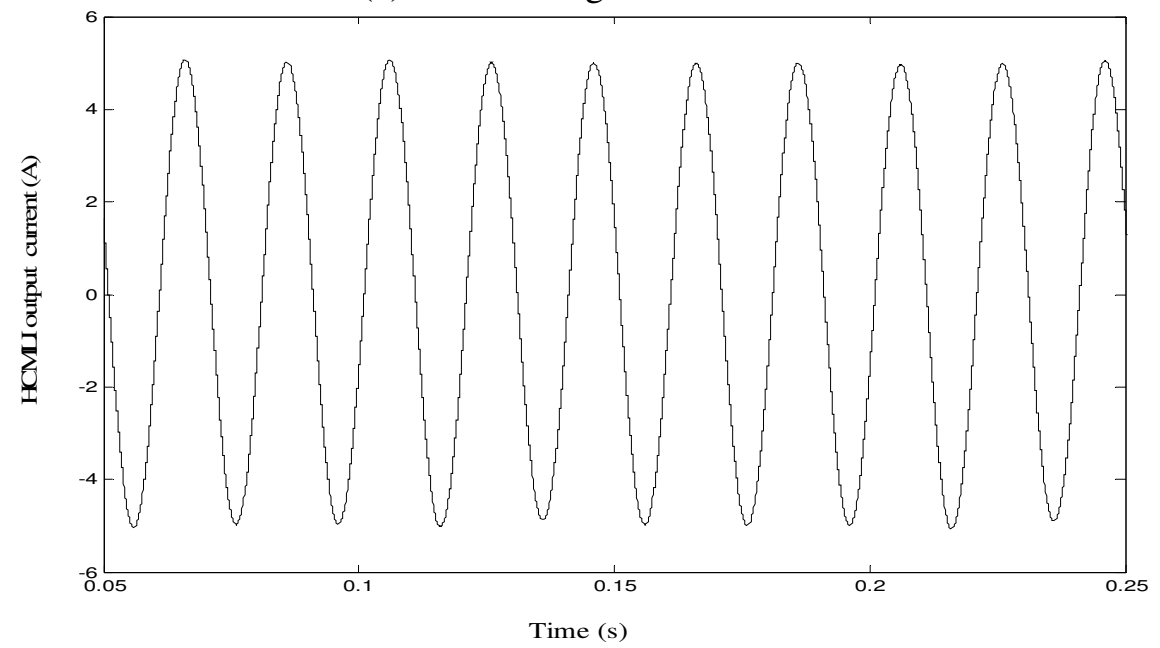

(b) Load current waveform of HCMLI

Figure .14 Load voltage and load current of HCMLI under steady- state operation

Figure.15 shows the simulated closed loop dynamic responses of load voltage and load current of fuzzy controlled HCMLI when the load changes from no load to full load suddenly at $\mathrm{t}=0.25 \mathrm{~s}$. 
Electrical and Electronics Engineering: An International Journal (ELELIJ) Vol 4, No 1, February 2015

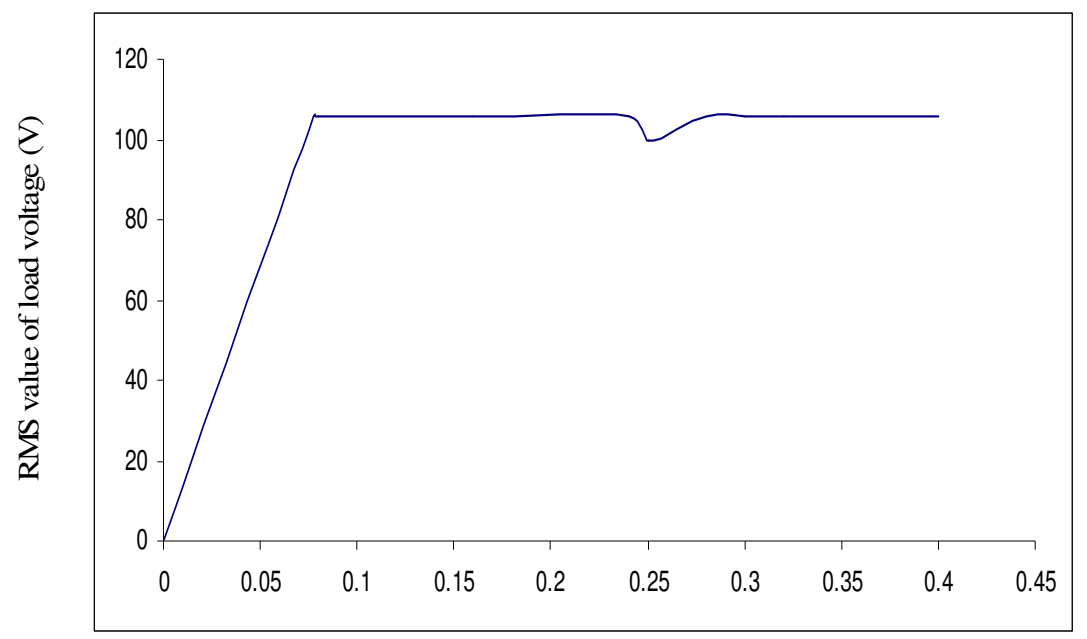

Time (s)

(a) Load voltage of HCMLI

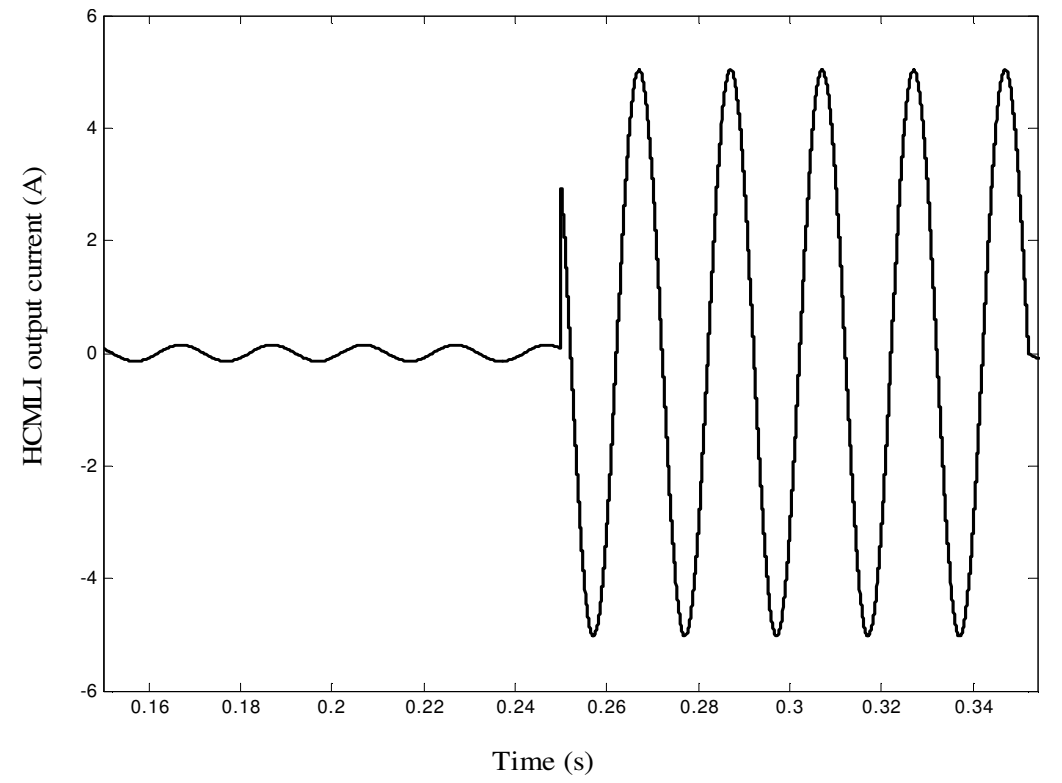

(b) Load current of HCMLI

Figure .15 Transient response of HCMLI with fuzzy control (no load to full load)

Figure .16 shows the simulated closed loop dynamic responses of load voltage and load current of fuzzy controlled HCMLI when the load changes from full load to no load suddenly at $\mathrm{t}=0.25 \mathrm{~s}$. 
Electrical and Electronics Engineering: An International Journal (ELELIJ) Vol 4, No 1, February 2015

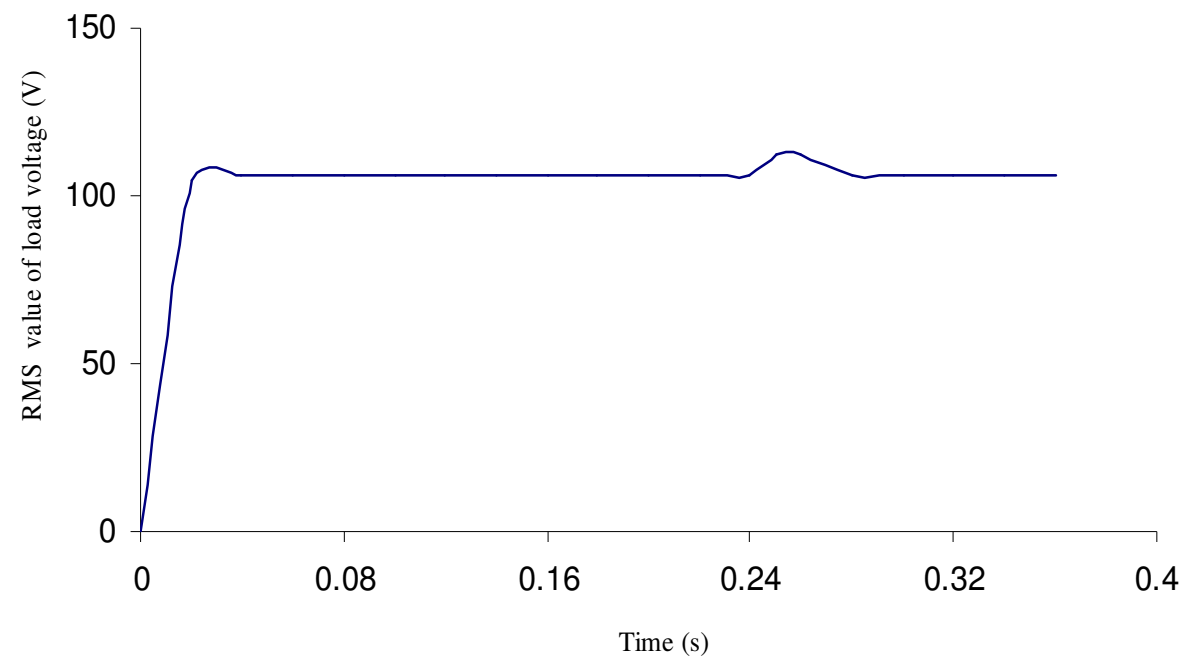

(a) Load Voltage Waveform of HCMLI

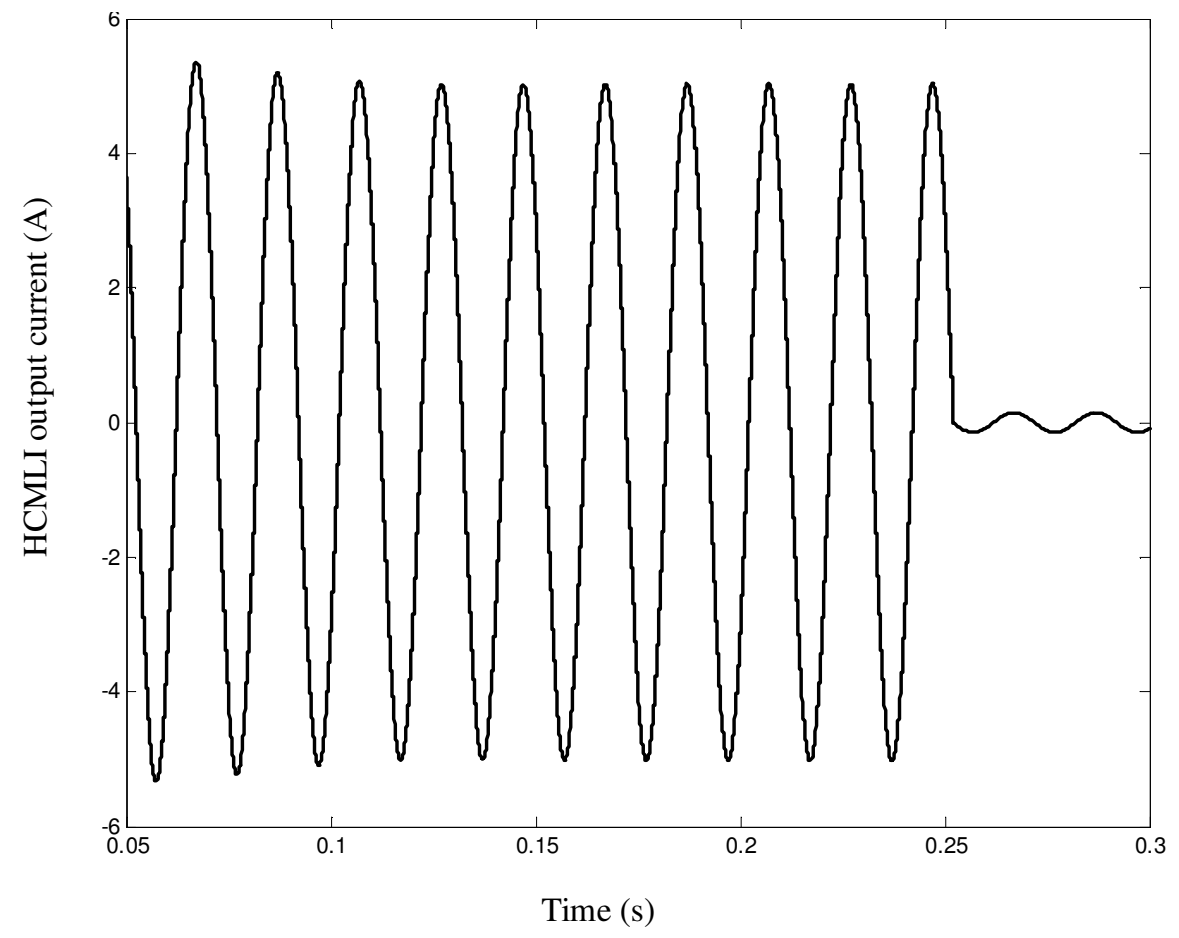

(b) Load current of HCMLI

Figure .16 Transient response of HCMLI using fuzzy control

\section{PERFORMANCE COMPARISON WITH PI CONTROLLER}

The performance of FLC for fuel cell based HCMLI is compared with PI controller. PI controller is tuned using Zeigler-Nichol first method $\left(\mathrm{k}_{\mathrm{p}}=0.001365\right.$ and $\left.\mathrm{k}_{\mathrm{i}}=35\right)$. The simulation circuit of IBC with PI controller is shown in Figure 17 and circuit for HCMLI with PI controller is shown in Figure 18. 
Electrical and Electronics Engineering: An International Journal (ELELIJ) Vol 4, No 1, February 2015

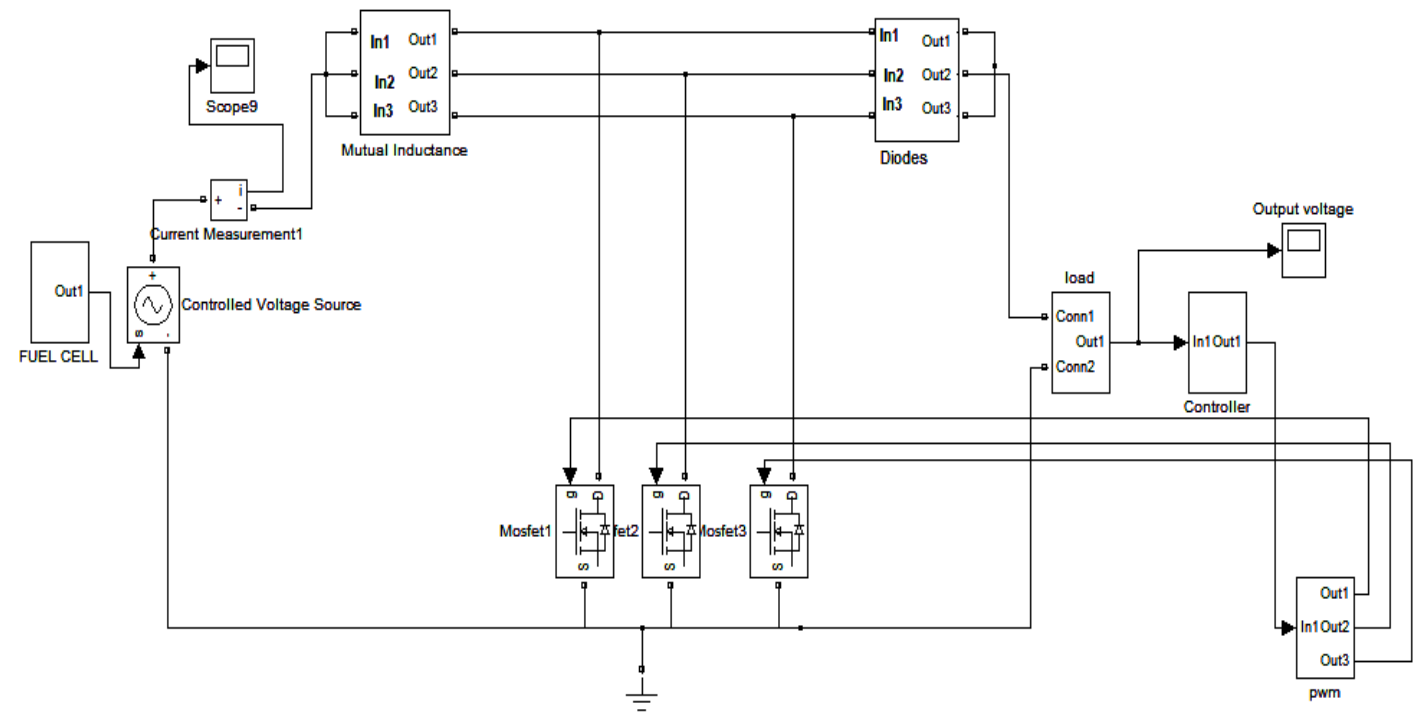

Figure .17 Closed loop simulation for FC interfaced with IBC (PI control)

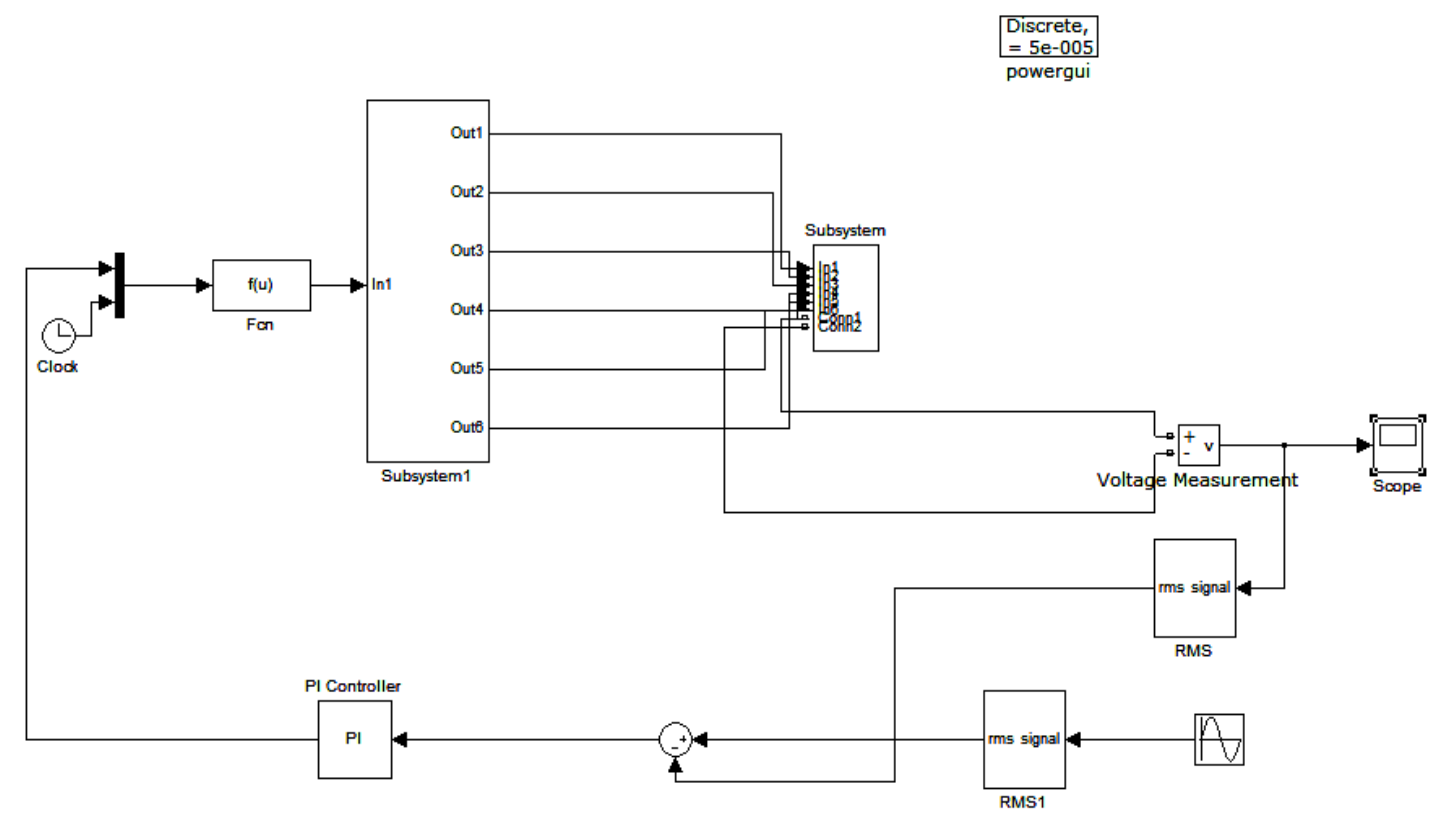

Figure .18 Closed loop simulation for HCMLI (PI Control)

The THD of simulated load voltage vs $\mathrm{m}_{\mathrm{a}}$ for HCMLI using PI and fuzzy logic controllers are shown in Figures 19 and 20 for various modulation indices. 
Electrical and Electronics Engineering: An International Journal (ELELIJ) Vol 4, No 1, February 2015

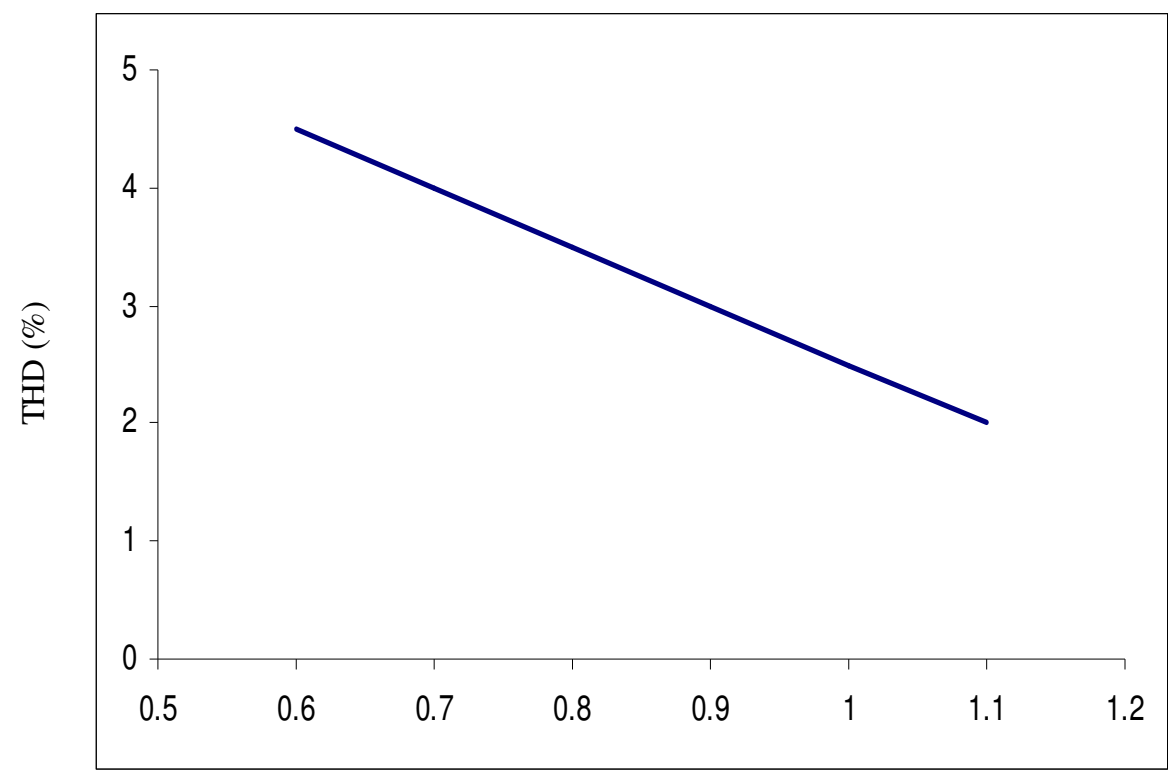

Modulation index

Figure .19 THD Vs ma for HCMLI using PI Controller

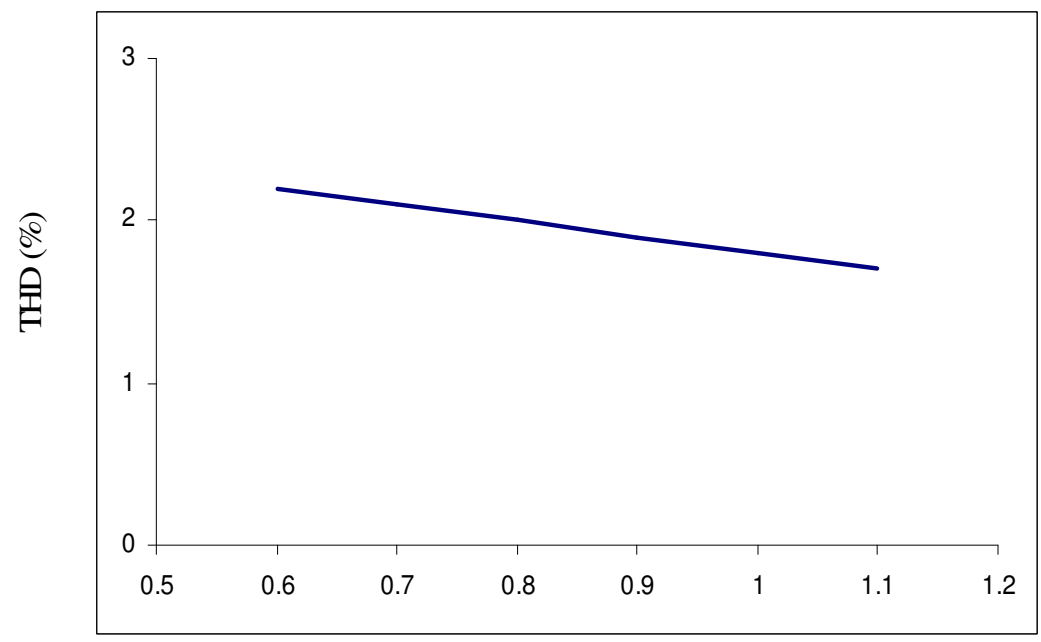

Modulation index

Figure .20 THD Vs ma for HCMLI using fuzzy logic Controller

From these results, it can be concluded that the fuzzy logic controller is the effective control strategy for HCMLI to achieve voltage output with low THD. 
Electrical and Electronics Engineering: An International Journal (ELELIJ) Vol 4, No 1, February 2015

\section{CONCLUSION}

In this paper, the design of fuzzy logic controller has been investigated for FC based HCMLI system. The performance of FLC is compared with that of PI controller. The fuzzy logic controller works effectively for step changes in load. Moreover, the local controllers of the fuel cell and power conditioning unit allow safer operation. Simulation results provide the overall system performance .It is further observed that the fuzzy logic controller works effectively and achieves an acceptable level of harmonic suppression compared to PI controllers.

\section{REFERENCES}

[1] Mohamed, S. N. F., Azil, N. A., Salam, Z. and Ayob, S. M. "Sugeno-type Fuzzy Logic Controller (SFLC) for a modular structured Multilevel Inverter", in Proc. 2nd International Conference on Power and Energy, PECON 2008, Malaysia, pp. 599-603, 2008.

[2] Goel, A., Mishra, S. and Jha, A. N. "Power Flow Control of a Solid Oxide Fuel-Cell for Grid Connected Operation," in Proc. International conference on Power Electronics, Drives and Energy Systems, pp. 1-5, 2006.

[3] Georgakis, D., Papathanassiou, S. and Manias, S. "Modeling and control of a small scale gridconnected PEM fuel cell system", in Proc. 36th IEEE Power Electronics Specialists Conference, PESC'05, pp. 1614-1620, 2005.

[4] Paddulés, J., Ault, G. W. and McDonald, J. R. "An approach to dynamic modeling of fuel cell characteristics for distributed generation operation”, in Proc. IEEE-PES Winter Meeting, Vol. 01, pp. 134-138, 2000.

[5] Dannenberg, K., Ekdunge, P. and Lindbergh, G. "Mathematical model of the PEMFC", Journal of Applied Electrochemistry, pp. 1377-1387, 2000.

[6] Nasiri, A., Rimmalapudi, V. S., Emadi, A., Chmielewski, D. J. and Al-Hallaj, S. "Active Control of a Hybrid Fuel Cell-Battery System”, in Proc. 4th International Power Electronics and Motion Control Conference, Vol. 2, pp. 491-496, 2004.

[7] Huber, L., Brian, T., Irving and Jovanović, M. M. "Closed-Loop Control Methods for Interleaved DCM/CCM Boundary Boost PFC Converters”, in Proc. IEEE Applied Power Electronics Conference and Exposition, APEC 2009, pp. 991-997, 2009.

[8] Shin, H. B., Park, J. G., Chung, S. K., Lee, H. W. and Lipo, T. A. "Generalized Steady-State Analysis of Multiphase Interleaved Boost Converter with Coupled Inductors”, in Proc. IEE Electronics Power Application, Vol. 152, No. 3, pp. 584-594, 2005.

[9] Jung, J. W. and Keyhani, A. "Control of a Fuel Cell Based Z-Source Converter", IEEE Trans. Energy Conversion, Vol. 22, Issue. 2, pp. 467-476, 2007.

[10] Seyezhai, R. and Mathur, B. L. "Modeling and Control of PEM fuel cell based Hybrid multilevel Inverter" in Proc. of the International Symposium on Fuel Cell Technologies(FUCETECH 2009), November 11-13, 2009, Naval materials Research Laboratory (NMRL), Mumbai. 